\title{
Introduction to Brazilian Constitutional Tax Law System
}

\author{
Renato Lopes Becho* ${ }^{(0)}$, Rafael Kaue Feltrim Oliveira ${ }^{\#}$ \\ Pontifical Catholic University of Sao Paulo, Sao Paulo, Brazil \\ Email: renatobecho@uol.com.br
}

How to cite this paper: Becho, R. L., \& Oliveira, R. K. F. (2021). Introduction to Brazilian Constitutional Tax Law System. Beijing Law Review, 12, 973-992. https://doi.org/10.4236/blr.2021.123050

Received: August 25, 2021

Accepted: September 24, 2021

Published: September 27, 2021

Copyright $\odot 2021$ by author(s) and Scientific Research Publishing Inc. This work is licensed under the Creative Commons Attribution International License (CC BY 4.0).

http://creativecommons.org/licenses/by/4.0/

\begin{abstract}
The main purpose of this article is to make a brief historical analysis of the Brazilian Tax Law System, outlining the intricacies and setbacks through which it came to be formed today through the Federal Constitution of 1988. The foundations that support the Federative Republic of Brazil will be listed, mainly with regard to the Constitutional Tax Law: the republican principle, the principle of legality, the principle of federalism and the principle of the due legal process, without which the Brazilian Tax System would not be possible. Finally, the article demonstrates the necessary steps to become a researcher in Brazilian tax law colleges and institutes, showing the current academic stage in which they are, through the process of interdisciplinary openness and internationalization at the Pontifical Catholic University of Sao Paulo (PUC/SP). As a bibliographical methodology, we confronted classical books-from Professors Ruy Barbosa Nogueira, Geraldo Ataliba, to Roque Antonio Carrazza-specific statutes-as the Brazilian Constitution of 1988as well as new academic works developed at PUC/SP.
\end{abstract}

\section{Keywords}

Post-Positivism, Brazilian Federal Constitution, Brazilian Tax Law System

\section{Introduction}

\subsection{A Brief Historical Background}

Brazil has historically adopted a Civil Law System-law based primarily on acts, statutes and codes, with the less importance being given to judicial precedents

*Bachelor's in law at UFMG (Belo Horizonte, Brazil, 1990), Cooperatives specialist at UNISINOS/ RS (1994), Master Degree (1997) and Ph.D. in Tax Law (2000) PUC/SP. Visiting research at King's College, London (2016). Tax Law Professor at PUC/SP. Federal Judge in São Paulo/SP, Brazil. "Bachelor's in law at PUC/SP (São Paulo, Brazil, 2016), Tax Law specialist at Instituto Brasileiro de Direito Tributário (IBDT) (São Paulo, Brazil, 2018), Master Degree at PUC/SP. 
and high reliance on legal scholarship, which means a reliable application of the principle of legality. The long Brazilian Federal Constitution of 1988 has maintained this tradition. However, things are changing.

The US Constitution launched a new chapter in the history of constitutionalism. Reflecting its time (1787), the previously experience (The Articles of Confederation), the situation of the country (13 States in the war against Great Britain) and the way that it was written (few men in closed doors) the US Constitution is a concise text with "less than eight thousand words".

The English Constitution is different, but it, too, reflects the history of the country. Accounted as an unwritten one, actually, it is a group of texts considered to represent the constitutional level. It reflects some of the most crucial moments for England, such as invasions in $55 \mathrm{BC}$ and 1066 and a revolution in 1649.

Professor Adam Tomkins mentions three situations under which a country adopts a written constitution: a revolution, an independency, or a defeat in war (Tomkins, 2003). With Brazilian constitutionalism, history has been the same, reflecting the past of the country.

However, shall we add another situation not mentioned by Professor Adam Tomkins: Coupe détat, as an occurrence that can produce a new constitution. A synthesis of our history indicates it: in 1822, Brazil became an independent country from Portugal and adopted a monarchical government, having its first Constitution in 1824; in 1889, a Coupe d état took down our Emperor, and a republic was proclaimed, with a new Constitution that came into effect in 1891; in 1930, a revolution installed a new government and another Charta came in 1934; the victorious president in the Revolution of 1930 brought about a Coupe de état in 1937 and issued our $4^{\text {th }}$ Constitution in the same year (1937); after II World War, and another Coupe de état in 1945, Brazil finally had a democratic Constitution in 1946, that endured till 1964, when the last Coupe détat ushered in a Military Dictatorship, with undemocratic Constitutions enacted in 1967 and 1969. Just in 1985, Brazil's Federal Congress approved a civilian president, who then called for democratic elections. In 1986, a National Constituent Assembly started to work, and, in 1988, the current democratic Charta was adopted.

\subsection{Brazilian Federal Constitution of $\mathbf{1 9 8 8}$}

The Brazilian Federal Constitution was a result of a National Constituent Assembly installed in 1986, composed of representatives and senators democratically and directly elected, all of whom represented large different political and ideological groups. The Assembly produced a long text with 250 articles and 70 others in a Temporary Constitution Provisions Act (the acronym in Portuguese is $A D C T$ ). The main text had 39,651 words and the ADCT 8125 words. The Charta intended to cover all critical aspects of the political, social and economic life, which appear in its nine titles (the primary division of the text): (I) fundamental principles, (II) fundamental rights and guarantees, (III) the organization 
of the State, (IV) the organization of the Powers, (V) the defense of the State and the democratic institutions, (VI) taxation and the budget, (VII) the economic and financial order, (VIII) the social order, and (IX) general constitutional provisions. Applying Adam Tomkins classification, it is a code, consisting not only of rules, but more important than these, consisting also of a plexus of principles that introduced multiple values in the Brazilian juridical system (Tomkins, 2003).

It is not simple to change this Charta, as its article 60 makes clear. However, until October 19 $9^{\text {th }}, 2021$ (after 32 years of the original text), the Constitution has been amended 110 times-despite the difficulty to change the Constitutionand now has around 57,000 words. These impressive figures show many things, some of them positive, others negative: Brazil has a vivid Constitution and not a simple symbol or figurative document without consequences.

The first important thing to recognize is that Brazil has a real Constitution that works as the primary source for the legal system-a crucial reference applied every day on Courts in the whole country. Notwithstanding, so many amendments indicate a lack of stability in the law and denote that the political forces changed after the National Constituent Assembly.

This instability - the lack of "legal certainty" - is a negative characteristic and reflects essential aspects of Brazilian political life that impacts all society.

By the way, changes in political forces are positive, indicating a truly democratic country. Our more recent rulers are a good example of this: a socialdemocratic (Fernando Henrique Cardozo, president from 1995 to 2002), two partially-left-wing presidents (Luis Inácio Lula da Silva, from 2003 to 2010; Dilma Rousseff, from 2011 to her impeachment in August 2016), and two rightwing presidents (Michel Temer, from 2016 to 2018; Jair Bolsonaro from 2019 until now).

We can say that the advent of the Constitution as the Law's higher document is the process by which the interpretative paradigms of all legal branches turn to the Magna Carta-more democratic and social, bringing in its core an exhaustive list of Fundamental Laws, Political and Social-getting from their devices the guidance needed to achieve their greater end: building a free, just and supportive society, ensuring national development, eradicating poverty and marginalization and reducing social and regional inequalities and promoting good of all, without prejudice of origin, race, gender, color, age and any other forms of discrimination.

As we look at European law, we can list some of the legal documents through which the constitutionalization process has paved its way: the German Constitution, called the Bonn Fundamental Law, in 1949 and the creation of the Federal Constitutional Court in Germany in 1951, the 1947 Constitution of Italy and the creation of the Constitutional Court of Italy in 1956, and the constitutions of Portugal-in 1976-and Spain in 1978.

This process of constitutionalization of the Law, which in the $21^{\text {st }}$ Century comes to be called neoconstitutionalism, brought to light the division between 
principles and rules, with their predominance, the supremacy of Fundamental Rights and the dignity of the human individual, the axiological and creative interpretation of the law, the predominance of judicial activity and the approximation of the Law to Morality.

In this way, the meaning of the Constitution, previously seen as a mere formal document by which the Powers of the States were divided and organized, and a few rights were granted, was altered in order to achieve the greatest possible effectiveness of its text-which becomes extensive, establishing a whole set of broad rights-governing all the facts of life, a role that had previously occupied civil law.

In a Tax Law context, we see that the constitutionalization process is based on important assumptions, initially, on the one hand, the principles, rules and institutes were raised to a constitutional level, so that, the taxpayers could be even more protected from an undue invasion of the State through the collection of taxes, so the vertical and imposing relationship whereby the individual is compelled to bring money to the State-either by the existence of presumptive signs of wealth or by the regulatory exercise of police power or use of public services-has to be in accordance with the Constitution and through a series of milestones, based on fundamental rights.

On the other hand, the collection, management and application of the amount brought to the State, by way of taxes, should take place democratically, fairly and with the ultimate goal of eradicating social and regional inequalities and ending poverty in the construction of a society aligned with social welfare.

According to Roque Antonio Carrazza, we note that the Brazilian Constitution of 1988, in the laudable purpose of transforming the Brazilian Republic into a democratic country based on the Rule of Law, has subjected the tax action to an extensive list of principles (federative, legality, equality, precedence, security), which protects taxpayers as much as possible against possible abuses. Moreover, it is the constitutional principles that drive the content of tax laws and their modes of application (Carrazza, 2010).

Thus, the collection of exactions and the lawful invasion of private property by the State must necessarily take into account the protection of fundamental rights, that is, respect for strict legality, proportionality, reasonableness, contributory capacity, material equality and non-retroactivity.

\subsection{Tax Law as a Constitutional Matter}

Taxation has been a well-developed subject in Brazilian Law since 1965. It occupies more than 2500 words in the current Federal Constitution (1988), half as many words as the entire US Constitution. If we add "public budget" to it (Title VI of the Brazilian Constitution is dedicated to taxation and budget), there are more words about public finance in the Brazilian Constitution than there are in the entire US Constitution. Besides, an interpreter needs to recognize that there are rules about taxes in other parts of the Brazilian Constitution (such as some 
immunities in article 5 and fees to sustain Social Welfare in article 195).

Nevertheless, Brazilian Tax Law, as an autonomous discipline, has also suffered major difficulties until its current consolidation, with its on principles, rules, legal relations and institutes and its own codification. Thus, today, we can say that the Brazilian Tax Law has autonomy.

Initially, the study of the Tax Law did not even have juridical character, since it was considered an aspect of the Financial and Economic Sciences-therefore extra-juridical-that took all the pertinent discussions to the matter-the amount that the taxpayers should take to the State and the subsequent application of the amount collected.

The autonomous status of the Tax Law discipline resulted from a long process of awareness and historical improvement in Brazil, which initially started from its insertion as an object of the Financial Science, then to be recognized as part of Financial Law-under the auspices, relations, institutes, and principles of Administrative Law.

One of the major jurists of the Brazilian Tax Lax, Geraldo Ataliba, states that didactically and practically, it was agreed to discern the part (the Tax Law) of the whole (Administrative Law), by the isolation of the fundamental institutions of that: the tax (Ataliba, 2011a).

Only then, by the efforts of several Brazilian jurists, it comes to acquire autonomy, with the creation of chairs in the Faculties of Law, through which its structure and dogmatic was established, that is, the factors and behaviors of human society that could generate the tax obligations, developing its interpretation, the types of taxes and the principles, rules and institutes of Tax Law, endowed with broad emancipation.

Regarding the Chair of Tax Law in the law schools of the country, it is considered as a historical landmark what occurred at the Pontifical Catholic University of São Paulo (PUC-SP), where, through the lectures of Professor Carlos Alberto Alves de Carvalho Pinto, the Science of Finance was taught.

With the entrance of Professor Ruy Barbosa Nogueira, the name of the Chair was changed to "Financial Law"-although his study was absolutely focused on Tax Law-and under the mastery of Professor Geraldo Ataliba, the birth of the first regular course of Tax Law in Brazil continued, which later occurred in several colleges of the country.

In the words of Ruy Barbosa Nogueira, with the approval of the Faculty of Law of the Pontifical Catholic University of São Paulo, was inaugurated the first course of Tax Law, which has been taught for fourteen years, whose course continues today, and in 1963 PUC-SP created the first Chair of Tax Law (Nogueira, 2002).

Publications, debates, comments and important works started by Rubens Gomes de Sousa, Aliomar Baleeiro, Gilberto de Ulhôa Canto, Amílcar Falcão, Tullio Ascarelli and, later, Ruy Barbosa Nogueira, Alfredo Augusto Becker, Alcides Jorge Costa, Geraldo Ataliba, José Souto Maior Borges, among many oth- 
ers, increasingly enriching the nascent tax literature, strongly influenced by Hans Kelsen's Legal Positivism.

These factors led, in 1953, to the first attempt to create a tax code in Brazil, by Rubens Gomes de Sousa, with the Draft National Tax Code sent to the National Congress in 1954. Nevertheless, despite heated debates, revisions and concerning to Gomes de Sousa's initial proposal-heavily influenced by the 1919 German Code-the Project remained suspended for 12 years, and only in 1966, the Congress approved the Act n. 5.172, entitled the National Tax Code (Portuguese acronym: CTN), in turn regulated in 1967 by the Complementary Act $n .36$ issued by the president of the Republic (at that time having legislative authority by virtue of the Military Coup d Etat). By means of this Complementary Act, CTN was considered a supplementary law.

The Brazilian constitutional tax law system was only introduced by the Constitutional Amendment Act n. 18 in 1965 (to the Federal Constitution of 1946) composing three types of tributes (taxes, fees, and a benefit charges); many specific principles works as limitations on the power to tribute (e.g., legality, equal treatment, non-retroactivity, non-confiscatory taxes, etc.); as well as some immunities (e.g., inter-government, houses of worship, political parties, trade unions, non-profit education and assistance institutions, books and newspapers). However, many other general principles affect the taxation system, such as the republican principle and the federalism principle.

Hence, the present system is the result of a slow, gradual and steady evolution in a coherent line having one concern at all times: to preserve and safeguard the constitutional rights of the Brazilian citizens (taxpayers).

To demonstrate how long our Constitution is, Roque Antonio Carrazza took article 1 ("The Federative Republic of Brazil, formed by the indissoluble union of the states and municipalities and of the Federal District, is a legal democratic state...") and has written almost 200 pages about it in his academic and professional tax law book (Carrazza, 2010). In order to analyze the whole chapter dedicated to the national taxation system in the Constitution, this book consists of more than 1000 pages. It confirms that any study of tax law in Brazil must start with many parts of the Federal Constitution.

Other examples can illustrate how complicated Brazilian constitutional tax law is. As Geraldo Ataliba teaches, a jurist must study the entire Constitution to know about the law. Writing about the republican principle, Ataliba pointed out that we must comprehend article 5 with its 78 items and four paragraphs ("individual and collective rights and duties") and Title VII, dedicated to economic and financial order, which occupies articles 170 to 192 of the Text (Ataliba, 2011b).

In this sense, Brazilian constitutional tax law continues to apply the Magna Carta principle "no taxation without representation". The Constitution stipulates that (article 48) "National Congress shall have the power, with the sanction of the President of the Republic (...) to provide for all the matters within the jurisdiction of the Union and especially on: I-a system of taxation, the collection 
of taxes and income distribution"; and, "article 150. Without prejudice to any other guarantees ensured to the taxpayers, the Union, the states, the Federal District and the municipalities are forbidden to: I-Impose or increase a tribute without a law establishing it".

There are many general principles that have direct connections with taxation. Here at least three of them are briefly commented: republic, federalism and due process of law.

\section{The major Principles}

\subsection{Republican Principle}

Even though the republican principle is not the primary subject of this paper, it is necessary to summarize a few situations when it works in the Brazilian taxation system, as we did before (Becho, 2015).

The principles are the main lines, the great and maximum guidelines of a legal system. The republican principle unfolds in countless rules, giving content to the tripartition of powers, political mandates (periodical, through direct, universal and secret voting), alternation of powers, responsibilities of public agents, protection of public liberties, accountability, mechanisms of government control and inspection, autonomy of entities (federation-as a necessary form of its realization), among others ${ }^{1}$.

According to Professor Geraldo Ataliba, the Republic is the political regime in which those exercising political functions (executive and legislative) represent the people and decide on their behalf, doing it responsibly, electively and through periodically renewable terms of office, presenting three fundamental characteristics: eletivity, the periodicity and responsibility of the political representative (in return for the powers granted), fundamental for the realization of individual and collective rights and the fundamental guarantees provided for in the Constitution ${ }^{2}$.

The first tenet of the republican principle is equality, and it is mentioned several times in the Brazilian Constitution (e.g. article $5^{\text {th }}$ : "All persons are equal before the law, without any distinction whatsoever..."; article $5^{\text {th }}$, incise I: "men and women have equal rights and duties under the terms of this Constitution"). In the chapter on the taxation system, the republican principle is highlighted in the following part:

Article 150. Without prejudice to any other guarantees ensured to the taxpayers, the Union, the states, the Federal District and the municipalities are forbidden to:

II-institute unequal treatment for taxpayers who are in an equivalent situation, it being forbidden to establish any distinction by reason of professional occupation or function performed by them, regardless of the legal designation of the incomes, titles or rights.

Because of that, the president of the Republic, as well as all politicians, judges, ${ }^{1}$ Ibid, p. 38-39.

${ }^{2} I b i d$, p. 27. 
member of the military, diplomats, civil servants, etc., must be treated equally by the law applicable to all private people. All of them are taxpayers and, for instance, if the president of the Republic receives the same income as a manager of a private company, both of them must pay the same income tax.

Another critical reflection of the republican principle is the division and independence of the branches of the Union: the Legislative, the Executive and the Judiciary (Federal Constitution, article $3^{\text {rd }}$ ).

To demonstrate the importance of it, it is necessary to remember the Moderator Branch, which was included in the first Brazilian Constitution (1824): "Article 10. The Political Branches recognized by the Constitution are four: the Legislative, the Moderator, the Executive and the Judiciary". This Branch was specified in articles 98 to 101 and was, actually, above the others, as the Emperor summoning the Parliament, approving the judges and, by article 102, exercising the most important action of Executive: nominating the Ministers. The Emperor wasn't responsible for anything (article 99).

Nowadays, applying the republican principle, anyone having a public function is held responsible, including the president of the Republic.

Considering that there hasn't been Moderator Branch in Brazil since 1889, the three Branches pointed out are independent, although it is imperfect, as the Executive strongly acts on Congress and nominates judges (except first instance ones).

Nevertheless, the independence of all Branches is essential to apply Human Rights in Tax Law and in Tax Procedural Law. That independence is also essential for dealing with systematical problems in tax enforcement. Otherwise, judges couldn't impose the law (statutes or acts) on attorneys acting as Executive lawyers.

In this context, the final interpretation of the law is made by the Judiciary, as was taught by Rui Barbosa, one of the most prestigious Brazilian jurists of all time:

[...] either the supreme adjudicator of our Constitutional Law is the Federal Supreme Court, or this oracular position, disputed between the two political powers, will end up merging everything into the Executive. The terms of the regime set forth in this manner, gentlemen, the Constitution of the Republic is the President (Barbosa, 1911).

This lesson can be expanded to the interpretation of all laws (statutes, acts, case law). In fact, the legal analysis belongs to the Judicial Branch. Otherwise, Executive would be transformed into a super branch, uncontested, supreme. Conceiving that tax acts regularly are a proposal to Congress by the Executive; Executive agencies do the first public interpretation, publishing interpretative documents (normative instructions); and Executive Agencies apply the acts; if those agencies have the last word (final examination), there would be no Tax Law, but tax dictatorship.

On the other hand, whether Judiciary is independent, the balance of the pow- 
ers is complete in Tax Law: the Executive proposes statutes (acts); the Legislative approves it; the Executive applies it; and the Judiciary makes the final interpretation of the law.

\subsection{Federalism Principle}

The Federation emerges as the association of States (foedus, foederis) for the formation of a new State (the federal) with a rigid distribution of the attributes of sovereignty among them. Their relationship is informed by the reciprocal autonomy of the Union and the States, under the aegis of the Federal Constitution, which characterizes this legal equality, given that both derive their competences from the same rule. Hence, each one is supreme in his sphere, as provided for in the Federal Pact (Ataliba, 2011b).

The Federation is a necessary form for the realization of the Republic, which takes place through political decentralization in order to bring representation closer to the people (mandators).

The federalism principle and the principle of municipality autonomy are both fundamental and general principles that affect the taxation system. Because of those principles, constitutionalists established that States and Municipalities have taxing authority. In other words, in the Brazilian Taxation System, there are tributes created by laws from the Union, the States, the Federal District and the Municipalities (hereby taxation entities).

Taxes in the strict sense were divided among them by the Constitution: the Union received authority to tax on (i) imports and exports of products; (ii) income; (iii) industrialized products; (iv) credit, foreign exchange and insurance transactions; (v) rural property; and, (vi) vast fortunes (not yet instituted). States can institute taxes on (i) transfers by death and donation of any property; (ii) transactions relating to the circulation of goods; and, (iii) ownership of automotive vehicles. The Municipalities can institute taxes on (i) urban buildings and urban land property; (ii) inter vivos transfer real estate; and, (iii) services. The Federal District can institute all taxes included in the competence of States and Municipalities.

According to article 145, item II, of the Constitution fees can be instituted "by virtue of the exercise of police power or for the effective or potential use of specific and divisible public services, rendered to the taxpayer or made available to him." Considering that every taxation entity has the authority to exercise some level of police power and public services, all of them (bodies) may institute fees. By way of example, to issue a passport comes under federal authority; consequently, the Union can collect fees by it. To issue driver's licenses comes under the authority of the States; accordingly, each of them can collect fees by it. Each Municipality must organize the construction of buildings; as a result, that Municipality is able to collect fees from issuing licenses to build.

The same occurs with benefit charges "resulting from public works" (Const., art. 145, III). If municipal public works increase the value of houses in an area 
(e.g., new pavement), the municipal Legislature may approve a law to institute a benefit charge for it; if a State should launch a new Metro line, it will be the same; if the Union constructs a new highway, the Federal Congress may publish a law to institute a federal benefit charge applied to owners of the areas that have increased in value by virtue of the new road.

Because of the foregoing, the federalism principle in Brazil has been extended to the tax law system and to each of the levels of government, as a result of which the States, the Municipalities and the Federal District have their own taxes, fees, and benefit charges.

The system of dividing the authority to create taxes was rigidly stipulated by the Constitution to protect the federation. But, more important than this, it was organized to protect taxpayers from many taxation entities:

Actually, this potential risk explains why taxation powers in Brazil have always been granted on an exclusive, privative and limited basis. It also explains the strictness with which the Brazilian Constitution has encircled the use of such powers by reducing to a minimum the possibility of their being used to create preferences, avoiding discrimination among persons, situations or assets.

In other words, to undertake a brief review of Brazilian tax law, one must understand the Federal Constitution, with special attention to 1) general principles, 2) specific taxation principles, 3 ) the different types of tributes and their divisions between political entities and 4) the immunities stipulated by the Federal Constitution.

\subsection{The Principle of Legality}

The principle of legality has been applied since the first Brazilian Constitution (1824), the $15^{\text {th }}$ article of which was dedicated to Legislative and stipulated that Parliament had "the power to make laws, interpret, suspend and revoke them".

The current Constitution (1988) establishes the same in article 5, item II: "No one shall be obliged to do or refrain from doing anything except by virtue of a law". Law, in this context, means act or statute, as can be interpreted by article 59 of the Constitution: "The legislative process comprises the preparation of: I-amendments to the Constitution; II-supplementary laws; III-ordinary laws; IV-delegated laws; V-provisional measures; VI-legislative decrees; VII-resolutions".

Gilmar Ferreira Mendes, commenting the article 5, II, of the 1988 Constitution, states that in the first quarter of the $19^{\text {th }}$ century, the 1824 Imperial Constitution incorporated the liberal postulate that all Law must be expressed through laws, and that this initial idea of the Empire of the Law, originated from the bourgeois ideals of the French Revolution, sought its inspiring source in Enlightenment thought, mainly in Rousseau, whose innovative concept at the time brought the law as a general rule and expression of the general will (volonté general), adding the generality of origin and object of the law and its considera- 
tion as an essential instrument for protecting the rights of citizens, which allowed, at first, to consolidate the new concept of law, typical of the Liberal State, expressed in article 4 of the 1789 Bill of Rights (Mendes, 2013).

Thus, the principle of legality represents the enshrinement of the premise that, while the individual can do whatever the law doesn't prescribe, the Public Administration can only carry out its activities in accordance with the law, doing only what the law says, as a presupposition of the complete submission of the Administration to the law, so that the exercise of its activities is restricted to obedience and compliance with legal rules (Mello, 2010).

Consistent with the Civil Law tradition, the Brazilian Legal System has many codes, each one addressing certain areas of law such as: Civil law, Civil Procedure, Criminal law, Criminal Procedure, Military Criminal law, Commercial law, Tax law, and Electoral law, among others. To understand the case analyzed below, it is worthwhile to point out the relevance of the Brazilian tax system, its National Tax Code and its tax legislation.

Subordinate to the National Tax Code, there are a number of rules from each entity of the Federation-rules such as tax codes enacted by the States, the Federal District and many Municipalities (but not all), as well as numerous supplementary and ordinary laws emanating from all entities.

According to a research, there were 25,101 statutes in force in September 2016. According to this research, 5,471,980 statutes have been enacted since 1988 (date on which the current Federal Constitution was adopted), which results in 45 tax-related laws for every working day.

This initial information with respect to our system confirms Professor Julcira Lisboa's commentary: "Brazilian Tax Law is not a system that can be easily understood, especially for those with no familiarity, because of its extremely complex character" (Lisboa, 2016).

\subsection{The Principle of the Due Process of Law}

The Principle of Due Process of Law dates back to the Magna Carta of 1215, from the English legal system, as well as to the "Statute of Westminster of London", also known as the "Law of Edward III or English Law of 1354".

According to Ada Pellegrini Grinover, the colonies of North America initially returned to the concept of law of the land, in the sense given by COKE and BLACKSTONE, and, later, the expression due process of law, from the tradition of English law, was transferred to the American Constitution, not only as a guarantee of legality, but also as a guarantee of justice, binding on all the branches of the State. Based on Roscoe Pound, she affirms that the due process of law is not an abstract concept from which absolute conclusions derive, applicable at any time, everywhere, but configuring itself as a standard that guides the court; that it has to be applied in view of the special circumstances of time, place, and the public opinion, as a proposition that offers open elements, whose concrete determination depends on the historical, political, economic and social 
conditions in force at the time it is applied (Grinover, 1973).

Under the Brazilian Constitution, in the article $5^{\text {th }}$ appears the due process of law principle, inserted at the following items:

Article 5. All persons are equal before the law, without any distinction whatsoever, Brazilians and foreigners residing in the country being ensured of the inviolability of the right to life, to liberty, to equality, to security, and to property, on the following terms:

LIV - no one shall be deprived of freedom or of his assets without due process of law;

LV-litigants, in judicial or administrative processes, as well as defendants, in general, are ensured of the adversary system and of full defense, with the means and resources inherent to it.

These two items of the "individual and collective rights and duties"- or, in other words, the principle of due process of law-is fundamental in the situation where the enforcement of tax duties will occur in the administrative or judicial processes.

Another important principle is "the reasonable length of proceedings": "LXXVIII-a reasonable length of proceedings and the means to guarantee their expeditious consideration are ensured to everyone, both in the judicial and administrative spheres".

The principle of due process of law applied to tax law confirms that republic is a fundamental constitutional principle, which draws together all areas of the law.

The Brazilian Judiciary Branch is regulated by the Federal Constitution, articles n. 92 to 126. It is made up of several bodies, with the Federal Supreme Court (STF) at the top. The STF's main function is to ensure compliance with the Constitution. Below it is the Superior Court of Justice (STJ), responsible for making a uniform interpretation of the federal legislation.

As we said before, Brazil is the fifth largest country and the fifth most populous in the world. In part, as a result, the Brazilian Judicial System has some impressive numbers: with jurisdiction over more than 208 million people, there are more than 1 million lawyers, 3 million holders of law degrees, and the breathtaking amount of half of the world's law schools; there are 1570 courts of first instances, as well as 91 appellate courts (86 state and 5 regional-federal Courts). In total, there were 17,349 judges, and 18.011 judges in 2016 in Brazil, and just in 2015 there were 27.3 million new cases brought in court (2.6 million of them were tax enforcement) and 28.5 million cases were finished. However, 2016 still started with 74 million judiciary cases in progress, $39 \%$ of which are cases of tax enforcement (28.8 million "old" cases). 2016 finished with 79.7 million judicial lawsuits (Becho, 2020).

In the Brazilian Judiciary system, there are bodies that operate within scopes of the Union and the States, including the Federal District and Territories.

The organization of the Union Justice, the Judiciary Branch, has the following units: the Federal Justice (common) including the special federal courts, and the 
Specialized Justice composed of the Labor Court, the Electoral Court and the Military Court.

The organization of the State Courts, which includes special civil and criminal courts, is the responsibility of each of the 26 Brazilian states and the Federal District, where the country's capital is located.

Both in the Federal Court and in the State Courts, the special courts are competent to judge cases of less offensive potential and of little economic value.

Normally, the lawsuits originate in the Trial court, composed of just one judge, and can be taken, through appeals, to the second level (Appellate court-normally composed of 3 judges), to the STJ (or other higher courts) and even to the STF, which gives the final word in legal disputes in the country in constitutional matters.

But there are cases that can originate in the second level or even in the Higher courts. This is the case of criminal proceedings against authorities with Privileged jurisdiction: representatives, ministers of state, the president of the Republic, among other authorities, have the prerogative of being judged by the STF when prosecuted for common criminal offenses. In these cases, the STJ is the competent body to judge governors. As for the second level of the common justice, it is up to the Courts of Justice to judge mayors accused of common crimes.

The Federal Court of the Union (common) is composed of federal judges who act in the first level and in the Federal Regional courts (second level), in addition to the special federal courts, by the competence established in the articles n. 108 and 109 of the Constitution.

For example, the Federal Court of the Union is responsible for prosecuting political crimes and criminal offenses committed against goods, services or interests of the Union (including municipal entities and public companies), processes involving a foreign State or international organization against a municipality or a person domiciled or resident in Brazil, causes based on treaties or contracts between the Union and a foreign State or international organization and lawsuits involving the rights of indigenous peoples and in cases of serious violation of human rights.

The Labor Court, one of the three branches of the specialized Federal Court of the Union, is regulated by the article n. 114 of the Federal Constitution. It is responsible for judging individual and collective conflicts between workers and employers, including those involving entities governed by external public law and the public administration of the Union, States, Federal District and Municipalities. It is made up of labor judges who serve at the first level and in the Regional Labor Courts (TRT), and by ministers who serve at the Superior Labor Court (TST).

The Electoral Court, which also integrates the specialized Federal Court, regulates electoral procedures, guaranteeing the constitutional right to direct and confidential voting. It is responsible for organizing, monitoring and counting the elections, as well as certifying the elected candidates. The Electoral Court has the power to decree the loss of federal and state elective mandate and judge ir- 
regularities practiced in the elections. It is composed of electoral judges who work at the first level and in the Regional Electoral Courts (TRE), and by ministers who work at the Superior Electoral Court (TSE). It is regulated by the articles n. 118 to 121 of the Constitution.

Military Justice is another branch of the specialized Federal Justice of the Union. It is composed of military judges who act in the first and second level and by ministers who judge in the Superior Military Court (STM). It is responsible for prosecuting and trying military crimes defined by law (articles n. 122 to 124 of the Constitution).

The State Court is composed of judges (who act in the first level) and by the chief judges, who act in the Courts of Justice (second level), in addition to the special civil and criminal courts. It is responsible for prosecuting and adjudicating any cause that is not subject to the jurisdiction of another jurisdictional body (Common Federal, Labor, Electoral and Military Justice), which represents the largest volume of litigation in Brazil. Its regulation is expressed in the articles $\mathrm{n}$. 125 to 126 of the Constitution.

The highest organ of the Brazilian Judiciary, the Supreme Federal Court is composed of 11 ministers appointed by the President of the Republic and approved by the Senate. Among the various powers of the STF, it is worth mentioning that of judging the direct unconstitutionality lawsuits (ADI, ADC and ADPF), a specific legal instrument to challenge the constitutionality of a federal or state law or normative act; consider requests for extradition requested by a foreign State; and judge a request for habeas corpus from any Brazilian citizen.

The STJ, which standardizes the national infra-constitutional law, is composed of 33 ministers appointed by the President of the Republic from a triple list drawn up by the Court itself. STJ ministers also must be approved by the Senate.

\section{The Study of Tax Law in Brazil}

\subsection{The Path to Become a Tax Law Professor in Brazil}

In Brazilian Faculties of Law, Tax Law occupies a distinct subject matter, as also is the case with Constitutional Law, Civil Procedural Law, Administrative Law, Human Rights, etc.

As explained before, from the 1950s until the advent of the Brazilian Constitution of 1988, the study of the Tax Law had grown exponentially, with numerous works towards the autonomous study of the subject. Still under a clear positivist bias, the academic productions about the tax institutes, principles and rules, the interpretation and application of the Tax Law, the taxes and their types, the tax obligation, the credit constitution, the launching and collection, the separation between Private Law and Tax Law, among other topics.

One of the doctrinal milestones of Brazilian Tax Law-which dates back to 1973, but must be read at the country's Law Colleges-was the launching of the book "Hypothesis of Tax Incidence" by Geraldo Ataliba, which nowadays ex- 
tends over time.

Geraldo Ataliba's work marked the definitive consolidation of the country's tax knowledge and from it, a school of great jurists is formed, which, as we will treat below, from the work of the Master and the new times brought after the State of Exception that prevailed in the country until the advent of the Charter of 1988, gave a new face to the Brazilian Tax Law, thus starting the studies of Constitutional Tax Law.

At Pontifical Catholic University of São Paulo-PUC/SP, one of the most prestigious of the Brazilian Faculties of Law, undergraduates must study three semesters of Tax Law, and may study another two optional semesters of Tax Law if they should so choose. In other words, students may explore Tax Law during half of the 5 years while pursuing a law degree. At the same University, Tax Law has been an object of a traditional post-graduation course (specialization, a 370-hours course) since 1973; and a Procedural Tax Law Course has been offered since 2001. There are two courses available for Master and Doctoral Degrees as well (Tax Law and Constitutional and Procedural Tax Law, the latter since 2015). An MSC degree should be completed in 30 months, and Ph.D. degree in 48 months.

To get a Master's degree in Law at PUC/SP, a student must take courses in six disciplines: one in the General Theory of Law, one in Philosophy of Law, and four in Tax Law or related areas such as Constitutional Law, Procedural Law or Administrative Law.

There are several institutes and think tanks dedicated to Tax Law in Brazil (such as the Finance Law Brazilian Association-ABDF, since 1949; the Brazilian Tax Law Institute-IBDT, since 1974; the Brazilian Tax Studies Institute-IBET, since 1977, and the Brazilian association of Tax Law-ABRADT, since 1996).

It is possible for Ph.D. professionals to get a Habilitation, which is a title one is entitled to after a contest in which the candidate, frequently a professor, proves his knowledge by writing a paper in five hours, reading it publicly, teaching for one hour (having 24 hours to prepare for it) and defending a thesis. The thesis will be expected to be more challenging than a Ph.D. thesis. There is a habilitation contest opened once a year at São Paulo University-USP, and there are internal habilitation contests for internal professors in PUC/SP and Rio de Janeiro State University-UERJ.

Habilitated professors may become a Full Professors at PUC/SP, USP, and UERJ.

\subsection{Tax Law Works Developed at PUC/SP}

There are many books dedicated to Tax Law. For instance, just thinking about professional textbooks that students use at law faculties as a guide and main text, currently, one may observe that professors in Tax Law at PUC/SP have written 5 of them. There are several other books written by professors at the same University about specific points and interests in Tax Law.

To illustrate how well tax law is developed academically in Brazil, we can take 
a look at some of the works, developed under multiple topics in the Constitutional and Procedural Tax Law nucleus at PUC/SP.

Many Professors of this nucleus, as Elizabeth Nazar Carrazza, Renato Lopes Becho, Roque Antonio Carrazza, Regina Helena Costa, Cássio Scarpinella Bueno, Julcira Maria de Mello Vianna Lisboa, Isabela Bonfá de Jesus, Estevão Horvath and Thais Helena Morando, for years, have developed a profound and fruitful study on Tax Law and its interrelationship with Constitutional Law, Tax Constitutional Law, Procedural and Tax Procedural Law, Financial Law, Philosophy of Tax Law and Human Rights related to Taxation, dealing with fundamental topics, such as on Contributory Capacity, Municipal Tax Law, Tax Equality, Tax Liability, Tax Immunities, Constitutional Limitations on the Power to Tax, Fundamental Principles, Taxation and social responsibility, tax exemptions, tax law and the environment, tax law and justice, law and development, among others topics, publishing more than 1028 works (including books, articles and papers), an impressive number, that can be raised even more if we take in consideration of all the assistant professors and researchers who collaborate with the nucleus.

Furthermore, it is important to emphasize that some research groups have been created, bringing together professors and students in favor of academic development. For example:

Elizabeth Nazar Carrazza (coordinator): a) Environmental Tax Law (DTA), studying and discussing fundamental constitutional values and aspects of Environmental Tax Law, articulating the work of the professors with the perspective of training new researchers and scientists in Law. It studies the link between Environmental Tax Law and the fundamental objectives of our Federal Constitution, preparing and contributing to teaching practice. It excels in its interdisciplinarity, inherent to the group's research, articulating with disciplines such as Constitutional Law, Tax Law, Environmental Law, Geography, Sociology and Planning. Systematic study on the legal regime of Environmental Tax Law, as the tax system outlined by the Constitution requires strict observance of the dignity of the human person in the institution of taxes, fees and contributions for improvement, given that society and democratic institutions aim to implement this principle of more varied forms; b) Effectiveness of the constitutional law on taxes, which aims to study taxes, in light of the Federal Constitution and the great principles it enshrines. It also aims to accurately trace the main rule of the various exaccional figures, in order to assess the constitutionality of the complementary legislation that deals with them.

Renato Lopes Becho (coordinator): a) Tax Obligation and Limitations on the Power to Tax, which aims to study taxation in Brazil, under the focus that it must be developed in accordance with a series of principles and rules that, in its great majority are found in the Federal Constitution. This gives taxpayers a series of rights and guarantees, which protect them against possible excesses. This time, the line of research revolves around the legal guidelines that grant taxpay- 
ers legal security in taxation, essential in our Democratic State of Law; b) Tax Procedural Law and System Protection, which aims to seek the effectiveness of the law in the tax process, both administrative and judicial, from the constitutional principles of regency (legal security, legality, equality, due legal process and the reasonable duration of the process) to its infra-legal texts of academic interest, notably aiming at the protection of the subjects involved. Considering that the tax process has the State as parties on the one hand and the taxpayer on the other (taxpayer, responsible or substitute), who will always be in a situation of imbalance, the aim is to create a forum for discussion in an attempt to rebalance this relationship. The aim is to study how the principles of due legal process and reasonable duration of the process inform and shape the administrative process and the tax judicial process, taking into account the sovereign choices made by the National Constituent Assembly and affirmed in the Federal Constitution of 1988, as well as the resulting from international treaties for the protection of Human Rights signed by the country and which impacted the performance of the derived constituents, having also been confirmed in the Constitution. In this context, it seeks to verify the use of the 2015 Code of Civil Procedure in tax matters, the application of the Tax Enforcement Law within constitutional parameters, as well as monitor the proposals for its replacement, among other legal diplomas, the reflection on the role of judicial decision in the formation of the legal norm, since it, the judicial decision, is governed by the Constitution and the CPC, and the possible approximation between the legal systems of Civil Law and Common Law, always against the backdrop of the tax legal relationship ; c) The Effectiveness of Cooperative Law, with the purpose of studying and stimulating national, international and interdisciplinary relations within the scope of cooperative law in its various fronts: constitutional, tax, administrative, civil and commercial, just to name a few. Therefore, we seek to study cooperative societies with forums of didactic autonomy within the Legal Sciences, so that, alongside theoretical issues, the legal provisions concerning the subject are addressed, considered in its broad and interdisciplinary character.

Roque Antonio Carrazza (coordinator): Constitutional Tax System and its informative principles, with the purpose to study the tax constitutional system, emphasizing its main guidelines, all in order to outline the limits of taxation in our country. Group members are carrying out constant research, in the doctrinal and judicial spheres. This work has resulted in a large number of doctrinal articles, dissertations and theses. This intellectual production aims to prepare the ground for the writing of more comprehensive works.

Nowadays, PUC/SP has been going through a process of interdisciplinary openness in tax law and internationalization, maintaining contact with international universities, receiving professors and researchers and teaching courses in English.

In a context of constitutional turn, a logical-semantic interpretation of Tax Law, aligned with the Legal Positivism and an already outdated reality, besides representing an innocuous formalism, is not in line with the social needs of the 
country and the maximum purposes of the Federal Constitution.

Thus, the plan of reality and the effective construction of a fraternal society, based on material equality, with the full guarantee of rights for all and liberation from poverty and injustice, demand, in fact, a logical-syntactic shift, with focus on interrelationship between individuals and institutions, a look at the reality of the subjects and not the dead letter of words, and there is, undoubtedly, a need for openness to an interdisciplinary approach (Hesse, 1991).

In this same sense, Ute Schmiel, making an evolutionary analysis of tax lawseen as a part of the economic analysis of law, so unmistakably an interdisciplinary approach-questions how to design adequate tax rules, understood as those rules which are compatible with market economy goals and that consider hypotheses of tax effect, showing the necessity to interpret tax rules as means to achieve tax goals:

"From a critical rationalist view, means-end-statements have an ethical and an empirical dimension. The ethical dimension implies that tax goals and tax rules as well as their secondary effects must be compatible with the aims of market economy regulation because the tax system is part of economic regulation. For this reason, the substantiation of tax objectives first needs a clear idea of the aims that market economy regulation (and therefore also the tax system) is supposed to fulfill. The empirical dimension of meansend-statements results from the postulate that ought implies can as well as from the fact that it is necessary to recognize also the secondary effects of tax rules in order to analyze them in an ethical perspective" (Schmiel, 2016).

Such statements are, in fact, very important, demonstrating that the tax system can't be understood, interpreted and applied alone, but, on the contrary, as part of economic regulation, even because taxes themselves influence economic activity and the way in which markets work, which demands an openness.

Thus, this openness represents a new paradigm whereby the whole phase of separation of the science of law and the autonomy of tax law has already been consolidated in such a way that there is no need for separation, but on the contrary, in a postmodern society in which reality is advancing at a rapid pace, the search for answers to the effectiveness of law and rights can and can often be found in other sciences, such as accounting, economics, psychology, medicine, computing, Sociology, and Morality.

\section{Conclusion}

Historically, Brazil has adopted a Civil Law system, based primarily on codes, through which a series of rules are laid out together, dealing with a given matter, and until then, judicial precedents had little importance in the country, emphasizing the predominance of the principle of legality and the binding, by the judge, to the literality of the text of the law.

This fact comes in a context of absorption of historical facts, and their legal 
consonants, which occurred in Europe, mainly the French Revolution of 1789 and the codification process imposed by Napoleon, in order to restrict the Judiciary Branch and expand the performance and importance of the Legislative Branch.

After numerous coups d'état, finally in 1988, Brazil promulgated a democratic Constitution, broad in matters and with great rigidity, based on major principles, as the principle of legality, the republican principle, the federalism principle and the due legal process principle.

Despite its 110 amendments, the promulgation of the democratic Constitution in the country, and the understanding, by scholars and jurists in general, of its undeniable importance, gave rise to the process of constitutionalization of the Law, and in the same sense, constitutionalization of Tax Law, through which the Federal Constitution became the legal, logical and interpretive paradigm.

In this sense, from the development of studies and the creation of the Tax Law chair at PUC/SP, through the efforts of countless professors, the process of constitutionalization and enrichment of the subject finally reaches its peak with interdisciplinary openness and internationalization.

Thus, from this article, an outline is made of the historical trajectory, institutes, and major principles of Brazilian Tax Law, enabling the opportunity to those who wish to both know and become researchers of Tax Law in Brazil.

\section{Conflicts of Interest}

The authors declare no conflicts of interest regarding the publication of this paper.

\section{References}

Ataliba, G. (2011a). Hipótese de Incidência Tributária (6th ed.). Malheiros.

Ataliba, G. (2011b). República e Constituição (3rd ed.). Malheiros.

Barbosa, R. (1911). Obras Completas de Rui Barbosa (Vol. XXXVIII, Tomo II). Fundação Casa de Rui Barbosa.

Becho, R. L. (2015). Lições de Direito Tributário (3rd ed.). Saraiva.

Becho, R. L. (2020). The Application of Judicial Precedents as a Way to Reduce Brazilians Tax Lawsuits. Beijing Law Review, 11, 730-731. https://doi.org/10.4236/blr.2020.113044

Carrazza, R. A. (2010). Curso de Direito Constitucional Tributário (26th ed.). Malheiros.

Grinover, A. P. (1973). As garantias constitucionais do direito de ação (15th ed.). Revista dos Tribunais.

Hesse, K. (1991). A Força Normativa da Constituição (1st ed.). Sergio Antonio Fabris Editor.

Lisboa, J. M. M. V. (2016). Brazilian Tax Law and the Principle of Legality. Claris.

Mello, C. A. B. (2010). Curso de Direito Administrativo (27th ed.). Malheiros.

Mendes, G. F. (2013). Comentários à Constituição do Brasil. Saraiva.

Nogueira, R. B. (2002). O surgimento e a evolução do ensino científico do direito tributário no Brasil. Revista Da Faculdade De Direito, Universidade De São Paulo, 97, 719-728. https://www.revistas.usp.br/rfdusp/article/view/67573 
https://doi.org/10.11606/issn.2318-8235.v97i0p719-728

Schmiel, U. (2016). Evolutionary Analysis of Tax Law: A Methodological Approach. Modern Economy, 7, 377-390. https://doi.org/10.4236/me.2016.74041

Tomkins, A. (2003). Public Law. Oxford University Press. 